\title{
Tribological performance of three fatty acid anion-based ionic liquids (FAILs) used as lubricant additive
}

\author{
N. Rivera ${ }^{\mathrm{a}}$, D. Blanco ${ }^{\mathrm{b}, *}$, J.L. Viesca ${ }^{\mathrm{b}, \mathrm{d}}$, A. Fernández-González ${ }^{\mathrm{c}}$ \\ R. González ${ }^{\mathrm{a}, \mathrm{d}}$, A. Hernández Battez ${ }^{\mathrm{b}, \mathrm{d}}$ \\ ${ }^{a}$ Department of Marine Science and Technology, University of Oviedo, Asturias, Spain \\ ${ }^{\mathrm{b}}$ Department of Construction and Manufacturing Engineering, University of Oviedo, Asturias, Spain \\ ${ }^{\mathrm{c}}$ Department of Physical and Analytical Chemistry, University of Oviedo, Asturias, Spain \\ ${ }^{\mathrm{d}}$ Department of Design and Engineering, Bournemouth University, Poole, BH12 5BB, UK \\ ${ }^{(*)}$ Email: blancoadavid@uniovi.es
}

\begin{abstract}
This paper studies the tribological behavior of three fatty acid anion-based ionic liquids: methyltrioctylammonium octanoate $\left(\left[\mathrm{N}_{8881}\right]\left[\mathrm{C}_{8: 0}\right]\right)$, methyltrioctylammonium laurate $\left(\left[\mathrm{N}_{8881}\right]\left[\mathrm{C}_{12: 0}\right]\right)$ and methyltrioctylammonium palmitate $\left(\left[\mathrm{N}_{8881}\right]\left[\mathrm{C}_{16: 0}\right]\right)$ used as additive at $0.5,1$ and $2 \mathrm{wt} \%$ in an ester base oil. The tribological experiments were performed in two different tribometers: a Bruker UMT-3 using a reciprocating "ball-on-disc" configuration for pure sliding tests and a Mini Traction Machine (MTM) for rolling/sliding tests. After sliding tests, the wear scar was analyzed by scanning electron microscopy with energy dispersive spectroscopy (SEM-EDS) and X-ray photoelectron spectroscopy (XPS). Sliding tests results showed both friction and wear reduction of the mixtures with respect to the ester only at $25^{\circ} \mathrm{C}$. The worse tribological behavior at $100{ }^{\circ} \mathrm{C}$ could be attributed to the moderate thermal stability of these ionic liquids. Under rolling/sliding conditions, samples displayed similar antifriction and ECR behavior than the base oil at high speeds, changing to a higher friction and lower ECR at low speeds and increasing temperatures. EDX analysis showed mainly the steel disc elements. The XPS oxygen signal showed higher amount of $\mathrm{C}=\mathrm{O}$ bond on the worn surface after reciprocating tests at $25^{\circ} \mathrm{C}$, which could be attributable to IL-surface interaction and can explain the better wear reduction performance.
\end{abstract}

Keywords: ionic liquid; friction; wear; lubricant additive

\section{Introduction}

Ionic liquids (ILs) can be defined as salts with a melting point lower than $100^{\circ} \mathrm{C}$. These novel substances have been found useful in a broad range of different applications such as extraction, catalysis, solvents, synthesis and lubrication [1-11]. Their use in lubrication science was reported for the first time in 2001 [12], and their increasing utility could be explained regarding their commercial availability plus the growing knowledge of their physicochemical and environmental properties [13-19].

On the other hand, the current high price of ILs provokes that their main application in lubrication is focused on their use as lubricant additives, improving their feasibility with respect to their use as a neat lubricant [3,20-24]. Despite this fact, most of ILs commonly used with lubrication purposes are immiscible («1 wt.\% solubility) in traditional nonpolar oils due to the ions being held together by ionic forces and hydrogen bonding [3]. Several studies have been published in the early work with ionic liquids as lubricant additives, using these ILs in oil-IL emulsions or blended at low concentrations in nonpolar oils [25-31].

The use of ILs as additive in non-polar oils improves the adsorption of the former on metallic surfaces due to the polar nature of these substances. This phenomenon was found in some researches by using an ester 
(polar compound) as additive in a non-polar oil (mineral or polyalphaolefin) [32-34]. In order to face the above-mentioned solubility problem of ILs, some authors have used polar base oils looking for improving solubility [35-44]. Besides, few works have tackled the use of ILs as an additive in fully formulated oils with the aim of improving the knowledge regarding compatibility between ILs and other lubricant additives $[3,45-50]$.

Traditional ILs studied as lubricant additives usually contain sulfur, phosphorus, halogens or heterocycles in their composition $[12,36,44,51]$. Recently, the synthesis and use of halogen- and metal-free ILs is gaining attention in developing more sustainable additives or lubricants, especially because of the fact that the environmental regulations are increasingly restrictive [52-54]. The huge design possibilities presented by ILs through the modification of cation or anion have made possible the development of new ILs with specific physical and chemical properties for a given application [55]. Obtaining environmentally friendly ILs with excellent lubricating properties constitutes an important challenge in the design of these compounds, minimizing environmental risks and contributing to sustainable development [56].

The use of fatty acids as an anion precursor in the synthesis of ILs was reported for the first time in 2013 [57] and few works about the use of these ionic substances in lubrication have been published [58-62]. In this work, three novel fatty acid anion-based ionic liquids (FAILs): methyltrioctylammonium octanoate $\left(\left[\mathrm{N}_{8881}\right]\left[\mathrm{C}_{8: 0}\right]\right)$, methyltrioctylammonium laurate $\left(\left[\mathrm{N}_{8881}\right]\left[\mathrm{C}_{12: 0}\right]\right)$ and methyltrioctylammonium palmitate $\left(\left[\mathrm{N}_{8881}\right]\left[\mathrm{C}_{16: 0}\right]\right)$ has been employed for the first time as lubricant additive in a base oil (ester) in order to evaluate their antifriction and antiwear properties.

\section{Experimental details}

\subsection{Chemicals}

In order to obtain the three fatty acid ionic liquids (FAILs) via metathesis synthesis, some reagents has been use including: octanoic, lauric and palmitic acids (all natural $298 \%$ ) as anion precursors, methyltrioctylammonium bromide ionic liquid $\left(\left[\mathrm{N}_{8881}\right][\mathrm{Br}]\right)(\geq 97 \%)$ as cation precursor, toluene $(99.8 \%)$, sodium hydroxide and ethanol solution $(70 \% \mathrm{w} / \mathrm{w})$. All these chemicals were supplied by Sigma-Aldrich S.A and employed without any further treatment. The oxidatively stable and low-viscosity Priolube 3970 polyol ester (employed commercially as a base fluid and an additive in a wide range of applications, such as both air compressor and turbine oils, among others) was kindly provided by Repsol S.A and used for the preparation of the lubricant mixtures. 


\subsection{Synthesis and chemical identification of FAILs}

Three novel FAILs: methyltrioctylammonium octanoate $\left(\left[\mathrm{N}_{8881}\right]\left[\mathrm{C}_{8: 0}\right]\right)$, methyltrioctylammonium laurate $\left(\left[\mathrm{N}_{8881}\right]\left[\mathrm{C}_{12: 0}\right]\right)$ and methyltrioctylammonium palmitate $\left(\left[\mathrm{N}_{8881}\right]\left[\mathrm{C}_{16: 0}\right]\right)$ were synthesized from natural fatty acids using a salt metathesis reaction. The FTIR and ${ }^{1} \mathrm{H}$ and ${ }^{13} \mathrm{C}$ NMR analyses were conducted to confirm the molecular structures of these synthesized FAILs. All these synthesis and identification processes were explained exhaustively in a previous work [54]. In addition, the FTIR and ${ }^{1} \mathrm{H}$ NMR analyses were performed for the base oil in a Varian 670-IR FTIR spectrometer equipped with a Golden Gate horizontal attenuated total reflectance (ATR) accessory and in a Bruker Nav 300 at $300 \mathrm{MHz}$ 7.0T using deuterated chloroform as solvent, respectively. ${ }^{1} \mathrm{H}$ RMN spectra shows the classical features of a long carbon chain ester: 0.87 ppm (m, R-CH $), 1.27$ ppm (m, R-CH $-\mathrm{R}), 1.58$ ppm (t, $\left.\mathrm{R}_{3} \mathrm{CH}\right), 1.79$ (s, R-C(=O)- $\left.\mathrm{CH}_{3}\right), 2.29$ ppm (t), $4.01 \mathrm{ppm}\left(\mathrm{s}, \mathrm{R}-\mathrm{O}-\mathrm{CH}_{3}\right)$. On the other hand, FTIR spectra (Fig. 1) exhibits a strong peak at 1740 $\mathrm{cm}^{-1}$. This peak comes from the stretching vibration of $\mathrm{C}=\mathrm{O}$ present in the ester group. Furthermore, the ester oil shows peaks at 1225 and $1104 \mathrm{~cm}^{-1}$, corresponding to the $\mathrm{C}-\mathrm{O}$ bond which accomplishes with the so-called Rule of Three [63].

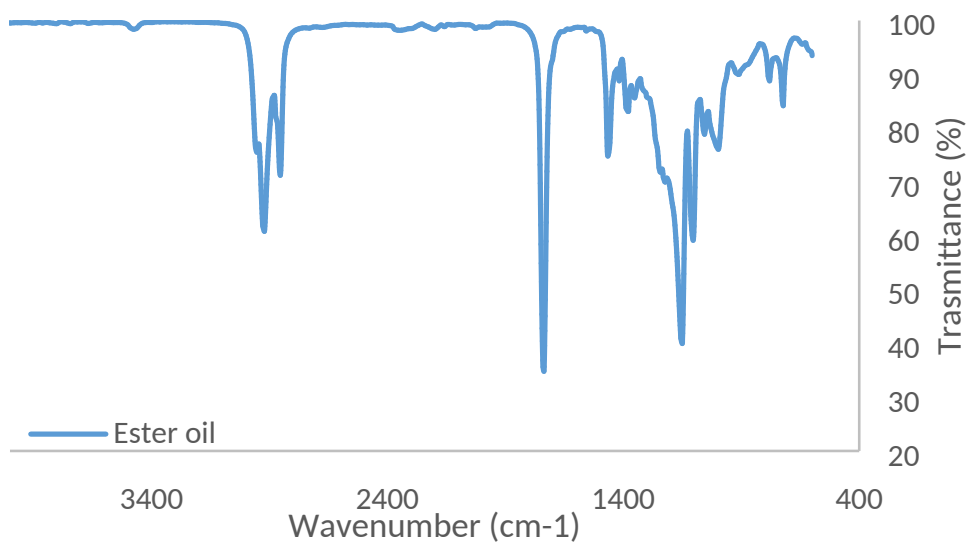

Fig. 1 FTIR Spectra of Priolube 3970 base oil.

\subsection{Density, viscosity and solubility}

The dynamic viscosity and density of the prepared mixtures was measured at atmospheric pressure according to ASTM D7042 in a range of 10 to $100{ }^{\circ} \mathrm{C}$ using a Coutte rotational viscometer (Stabinger SVM3000). The solubility of the FAILs in the base oil was measured in an aging Turbiscan station, which uses a "Multiple Light Scattering" measurement technology. These solubility tests were carried out at 30 ${ }^{\circ} \mathrm{C}$ using mixtures containing $0.5,1$ and $2 \mathrm{wt} . \%$ of ionic liquid. The measurements were made every $24 \mathrm{~h}$ and the appearance or absence of phases was checked visually for 14 days. 


\subsection{Tribology tests}

A UMT-3 tribometer (Bruker Corporation) with a steel-steel reciprocating ball-on-disc configuration was used to perform assays at two temperatures $\left(25\right.$ and $\left.100^{\circ} \mathrm{C}\right)$ with the following test conditions: load of 50 $\mathrm{N}$ (equivalent to maximum contact pressure of $2.43 \mathrm{GPa}$ ), $15 \mathrm{~Hz}$ frequency, $4 \mathrm{~mm}$ of stroke length and relative humidity in the range $40-60 \%$. These tests lasted 30 min using $4 \mathrm{~mL}$ of lubricant sample (neat base oil or mixture). The coefficient of friction (COF) was measured during the assay and the average value and its corresponding standard deviation was calculated through 3 different replicas. In addition, wear volume on the disc was determined by using a Leica DCM 3D confocal microscope. The test specimens employed during the tests were: AISI 52100 steel balls $(0.98-1.1 \% \mathrm{C}, 0.15-0.30 \% \mathrm{Si}, 0.25-0.45 \% \mathrm{Mn}, 1.30-1.60 \%$ $\mathrm{Cr}, 0.025 \% \mathrm{P}, 0.025 \% \mathrm{~S}$ ) with a diameter of $6 \mathrm{~mm}$, hardness of $58-66 \mathrm{HRC}$ and a surface roughness (Ra) of $0.05 \mu \mathrm{m}$; and discs of AISI steel 52100 with a hardness of $225 \mathrm{HV}$ and surface roughness (Ra) of 0.018 $\mu \mathrm{m}$. Before each test, the specimens were cleaned with heptane in an ultrasonic bath for $5 \mathrm{~min}$, rinsed in ethanol and dried with hot air.

A Mini Traction Machine tribometer (PCS Instruments) was used to study the lubrication behavior of the same samples previously tested with the UMT under different lubrication regimes. A ball-on-disc configuration with a rolling-sliding ratio (SRR) of 50\% was used, at an average speed between 2500 and $10 \mathrm{~mm} \cdot \mathrm{s}^{-1}$ (steps of $100 \mathrm{~mm} \cdot \mathrm{s}^{-1}$ from 2500 to 100 and steps of $10 \mathrm{~mm} \cdot \mathrm{s}^{-1}$ from 100 to 10 ), at a load of 30 $\mathrm{N}$ (corresponding to maximum contact pressure of $0.95 \mathrm{GPa}$ ), temperatures of $40,60,80$, and $100^{\circ} \mathrm{C}$, with a volume of lubricant sample of $10 \mathrm{~mL}$. The average velocity can be defined used Eq. (1) and the sliding speed as $\left(u_{d}-u_{b}\right)$, where $u_{d}$ and $u_{b}$ are the velocity of the disk and the ball at the point of contact, respectively. Finally, the sliding rolling ratio (SRR) was calculated using Eq. (2).

$$
\begin{gathered}
u_{m}=\frac{u_{d}+u_{b}}{2} \\
\operatorname{SRR}(\%)=\frac{2\left(u_{d}-u_{b}\right)}{\left(u_{d}+u_{b}\right)} \times 100
\end{gathered}
$$

$\mathrm{COF}$ and electrical contact resistance (ECR) were measured during the tests. An additional type of experiment was carried out with the aim of evaluating the effect of the sliding-rolling ratio (SRR): a load of $30 \mathrm{~N}$ (corresponding to maximum contact pressure of $0.95 \mathrm{GPa}$ ) with a rolling speed of $2000 \mathrm{~mm} \cdot \mathrm{s}^{-1}$ and SRR varying from 5 to $50 \%$. COF values were measured for each lubricant sample at four different temperatures $\left(40,60,80\right.$ and $\left.100^{\circ} \mathrm{C}\right)$. 
The specimens (balls and discs) were cleaned with heptane in an ultrasonic bath for 5 min, rinsed in ethanol and dried with hot air before each test. The specimens used during the tests were: AISI 52100 steel balls with a diameter of $19.05 \mathrm{~mm}(3 / 4 ")$, hardness of 800-920 HV and a surface roughness (Ra) less than 0.02 $\mu \mathrm{m}$; and discs of AISI 52100 steel with a diameter of $46 \mathrm{~mm}$, with a hardness of 720-780 HV and a surface roughness $(\mathrm{Ra})$ less than $0.02 \mu \mathrm{m}$.

\subsection{Surface characterization}

In order to study and evaluate the chemical interaction of the mixtures with the surface, scanning electron microscopy (SEM), energy dispersive spectroscopy (EDS) and X-Ray photoelectron spectroscopy (XPS) techniques were used after all reciprocating ball-on-disc tests. A JEOL-6610-LV SEM with tungsten filament electron gun working at $20 \mathrm{kV}$ of acceleration voltage, a maximum resolution of $3.0 \mathrm{~nm}$ (high vacuum mode) from x 5 to $\mathrm{x} 50000$ increases and a secondary electron detector was used. Microanalysis equipment integrated in the microscope has an SDD detector model Xmax 50 with linear resolution of 125 $\mathrm{eV}$ in $\mathrm{Mn} \mathrm{K \alpha}$ from 1 to $20000 \mathrm{cps}$ and active area of $50 \mathrm{~mm}^{2}$. The detection and quantification of elements is from atomic number 4 (Beryllium) and the ultra-thin window allows detection and analysis of ultralights (C, N, O ...). Complete integrated software Oxford INCA allows to select points or areas for analysis on the microscopic image. XPS measurements were made with a monochromatized source using the $\mathrm{K}_{\alpha}(\mathrm{Al})$ as anode $(1486.7 \mathrm{eV})$ at $45^{\circ}$. The $3.5 \times 1 \mathrm{~mm}^{2} \mathrm{X}$-Ray spot was focused on the wear scar in every sample. The binding energy was calibrated using the adventituos carbon at $284.6 \mathrm{eV}$. High resolution spectra were taken using a step energy $0.1 \mathrm{eV}$ with a pass energy $30 \mathrm{eV}$. The number of spectra averaged depended on the sample and the element assayed.

\section{Results and discussion}

\subsection{Density, viscosity and solubility}

The density and viscosity of these fatty acid anion-based ionic liquids were studied in a previous research [60], showing that both properties decrease with the increase of the alkyl length of the anion. It should be noted that the addition of these ionic liquids in weight concentrations of $0.5,1$ and $2 \%$ hardly modifies the density, viscosity and viscosity index of the base oil (Table 1). 
Table 1: Density and viscosity values of the lubricant samples.

\begin{tabular}{|c|c|c|c|c|}
\hline \multirow[t]{2}{*}{ Lubricant samples } & \multirow{2}{*}{$\begin{array}{c}\text { Density, } 20^{\circ} \mathrm{C} \\
\left(\mathrm{g} \cdot \mathbf{c m}^{-3}\right)\end{array}$} & \multicolumn{2}{|c|}{$\begin{array}{c}\text { Kinematic viscosity } \\
\left(\mathrm{mm}^{2} \cdot \mathrm{s}^{-1}\right)\end{array}$} & \multirow{2}{*}{$\begin{array}{c}\text { Viscosity index } \\
\text { (VI) } \\
\text { ASTM D2270 }\end{array}$} \\
\hline & & $40^{\circ} \mathrm{C}$ & $100^{\circ} \mathrm{C}$ & \\
\hline $\mathrm{BO}$ & 0.9417 & 20.5 & 4.54 & 140 \\
\hline $\mathrm{BO}+0.5 \%\left[\mathrm{~N}_{8881}\right]\left[\mathrm{C}_{8: 0}\right]$ & 0.9415 & 20.2 & 4.50 & 140 \\
\hline $\mathrm{BO}+1 \%\left[\mathrm{~N}_{8881}\right]\left[\mathrm{C}_{8: 0}\right]$ & 0.9417 & 20.5 & 4.53 & 140 \\
\hline $\mathrm{BO}+2 \%\left[\mathrm{~N}_{8881}\right]\left[\mathrm{C}_{8: 0}\right]$ & 0.9409 & 20.7 & 4.55 & 138 \\
\hline $\mathrm{BO}+0.5 \%\left[\mathrm{~N}_{8881}\right]\left[\mathrm{C}_{12: 0}\right]$ & 0.9415 & 20.2 & 4.50 & 140 \\
\hline $\mathrm{BO}+1 \%\left[\mathrm{~N}_{8881}\right]\left[\mathrm{C}_{12: 0}\right]$ & 0.9413 & 20.5 & 4.54 & 141 \\
\hline $\mathrm{BO}+2 \%\left[\mathrm{~N}_{8881}\right]\left[\mathrm{C}_{12: 0}\right]$ & 0.9411 & 20.3 & 4.46 & 135 \\
\hline $\mathrm{BO}+0.5 \%\left[\mathrm{~N}_{8881}\right]\left[\mathrm{C}_{16: 0}\right]$ & 0.9414 & 20.0 & 4.48 & 140 \\
\hline $\mathrm{BO}+1 \%\left[\mathrm{~N}_{8881}\right]\left[\mathrm{C}_{16: 0}\right]$ & 0.9413 & 20.5 & 4.55 & 141 \\
\hline $\mathrm{BO}+2 \%\left[\mathrm{~N}_{8881}\right]\left[\mathrm{C}_{16: 0}\right]$ & 0.9407 & 20.3 & 4.55 & 143 \\
\hline
\end{tabular}

In order to determine the solubility of the three ionic liquids in the base oil, a simple visual experiment was carried out for a first approximation. Samples were prepared at 5\% by weight of each ionic liquid in the base oil and, after manual agitation, the resulting mixture was visually monitored for 2-3 days without exhibiting phase separation. To verify this result, an additional experiment was made. Two mixtures at 0.5 and 2 wt.\% of ionic liquid in the base oil were prepared by mechanical agitation (5000 rpm, $2 \mathrm{~min})$ and then the evolution of the blends was observed in a Turbiscan aging station at $30{ }^{\circ} \mathrm{C}$ for 14 days. The measurement of light transmission was taken every $24 \mathrm{~h}$. It was found that all mixtures were stable during the 14 days of the solubility test.

\subsection{Tribological performance at 25 and $100^{\circ} \mathrm{C}$}

Fig. 2 shows the COF evolution during tribological tests at $25^{\circ} \mathrm{C}$, comparing the base oil with the highest concentration sample (2 wt.\%) of each FAIL studied. All three mixtures slightly improved the base oil friction performance at the end of the 30 min test. In addition, Fig. 2 also includes the mean coefficient of friction and the standard deviation of all tests carried out. Although all 10 samples showed similar mean friction coefficient, the lubrication with the $2 \mathrm{wt} . \%$ of $\left[\mathrm{N}_{8881}\right]\left[\mathrm{C}_{8: 0}\right]$ had the best result with more than a $4 \%$ of improvement regarding the base oil. The mixtures containing $1 \mathrm{wt} . \%$ of ionic liquid behaved equal to the base oil. Also, there was no reduction in friction coefficient using the mixtures with $0.5 \mathrm{wt} . \%$ of IL. 

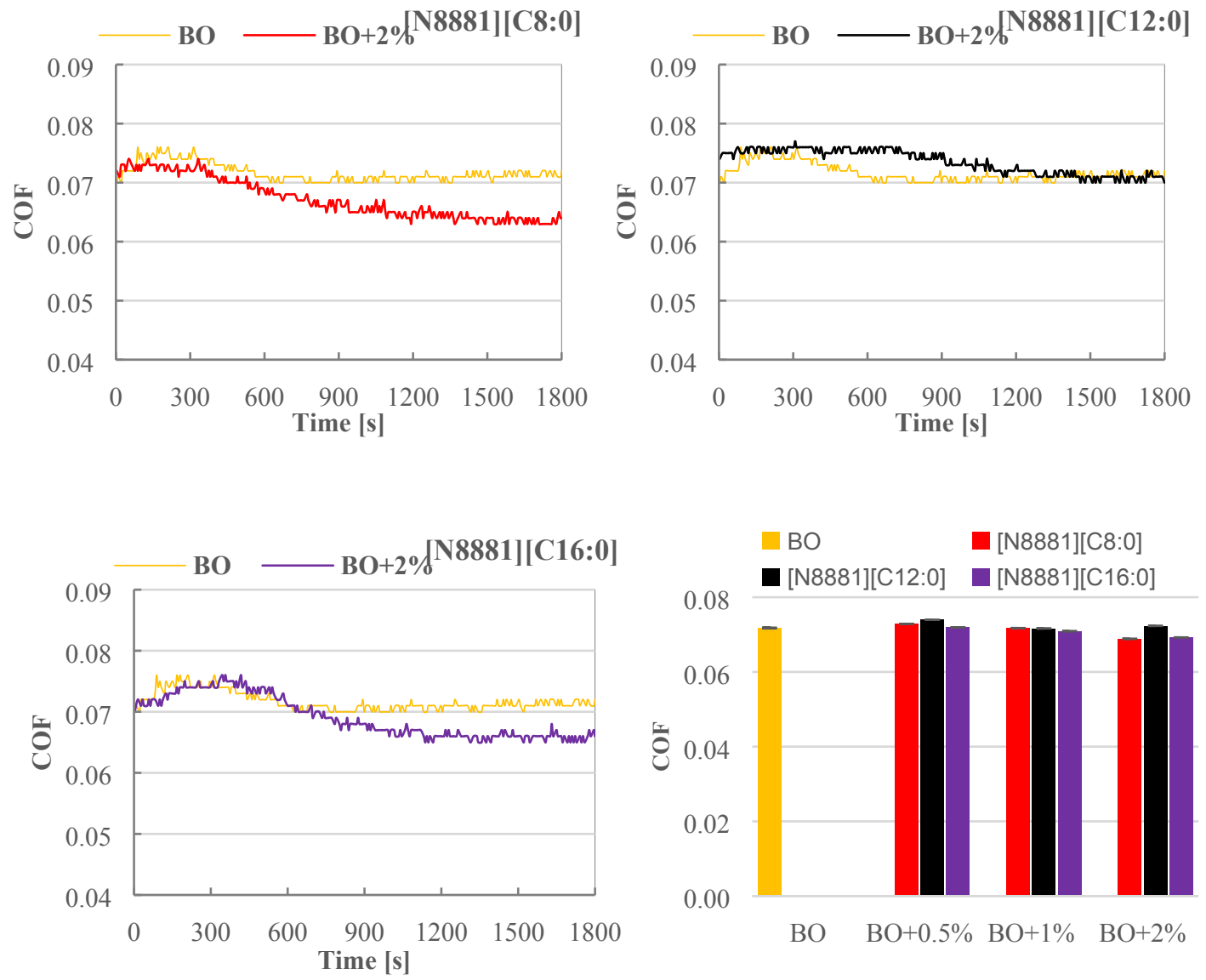

Fig. 2 Evolution of coefficient of friction during tribological tests $\left(25^{\circ} \mathrm{C}\right)$ and average COF values.

On the other hand, the friction coefficient evolution at $100{ }^{\circ} \mathrm{C}$ of the base oil and the blends with the highest IL concentration (Fig. 3) had different behavior to that at $25^{\circ} \mathrm{C}$. The mixtures containing $\left[\mathrm{N}_{8881}\right]\left[\mathrm{C}_{8: 0}\right]$ had identical average COF values to that of the pure base oil; meanwhile, the mixtures with $\left[\mathrm{N}_{8881}\right]\left[\mathrm{C}_{12: 0}\right]$ showed slightly higher COF than the base oil. In addition, the mixtures containing $\left[\mathrm{N}_{8881}\right]\left[\mathrm{C}_{16: 0}\right]$ led to higher COF values at increasing IL concentration from a lowest value similar to that of the base oil. These results could be related to the lower thermal stability of these fatty acid anion-based ionic liquids [60] in comparison with other ILs sharing the same cation [64,65], which negatively affect their friction performance at high temperatures. 

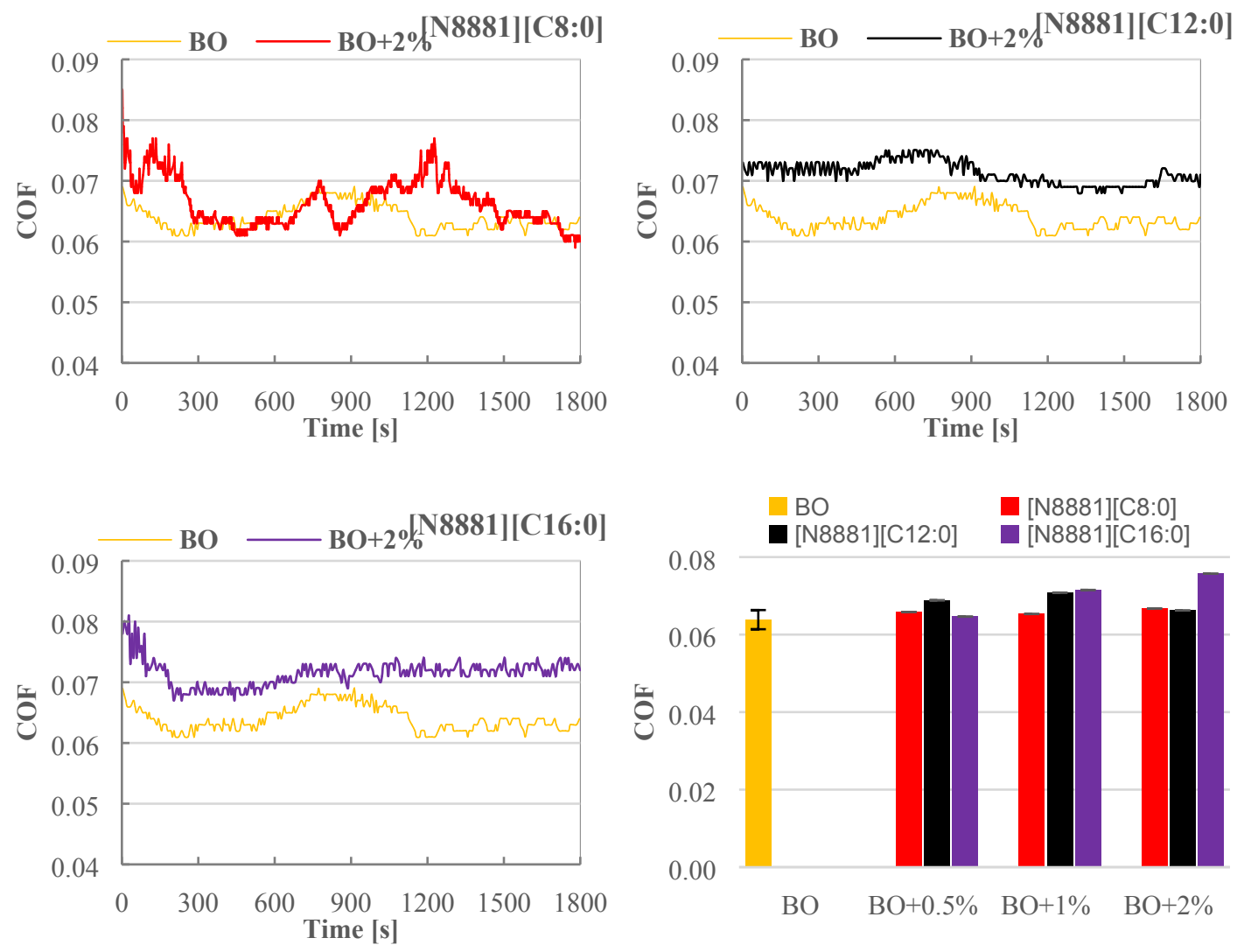

Fig. 3 Evolution of coefficient of friction during tribological tests $\left(100^{\circ} \mathrm{C}\right)$ and average COF values.

Table 2 exhibits the average wear values obtained with all lubricant samples, and their standard deviation and relative error. All the mixtures outperformed the base oil at $25^{\circ} \mathrm{C}$, with relative errors lower than $10 \%$. The $\mathrm{BO}+2 \%\left[\mathrm{~N}_{8881}\right]\left[\mathrm{C}_{8: 0}\right]$ sample was the best with more than $20 \%$ of wear reduction with respect to the base oil. Besides, $\mathrm{BO}+0.5 \%\left[\mathrm{~N}_{8881}\right]\left[\mathrm{C}_{12: 0}\right]$ showed nearly an $8 \%$ of wear reduction and both $\mathrm{BO}+$ $1 \%\left[\mathrm{~N}_{8881}\right]\left[\mathrm{C}_{16: 0}\right]$ and $\mathrm{BO}+2 \%\left[\mathrm{~N}_{8881}\right]\left[\mathrm{C}_{16: 0}\right]$ presented values between 10 and $15 \%$ of wear reduction in comparison with the neat base oil.

On the other hand, the wear behavior at $100^{\circ} \mathrm{C}$ was quite different to that at $25^{\circ} \mathrm{C}$. The wear values obtained with some blends were bigger than that obtained with the base oil, mainly with the $\left[\mathrm{N}_{8881}\right]\left[\mathrm{C}_{8: 0}\right]$ containing mixtures. These wear results and the lower repeatability could be related with the lower thermal stability of these fatty acid anion-based ionic liquids, which worsen the tribological behavior at high temperatures. 
Table 2. Wear volume on the disc's surface.

\begin{tabular}{|c|c|c|c|c|}
\hline \multirow[b]{2}{*}{ Lubricant sample } & \multicolumn{2}{|c|}{$25^{\circ} \mathrm{C}$} & \multicolumn{2}{|c|}{$100^{\circ} \mathrm{C}$} \\
\hline & $\begin{array}{c}\text { Avg. wear } \\
\text { volume } \pm \sigma \\
\left(\mu m^{3} \times 10^{6}\right)\end{array}$ & $\begin{array}{c}\text { Error } \\
(\%)\end{array}$ & $\begin{array}{c}\text { Avg. wear } \\
\text { volume } \pm \sigma \\
\left(\mu m^{3} \times 10^{6}\right)\end{array}$ & $\begin{array}{c}\text { Error } \\
(\%)\end{array}$ \\
\hline $\mathrm{BO}$ & $8.65 \pm 0.04$ & 0.47 & $8.41 \pm 0.11$ & 1.29 \\
\hline $\mathrm{BO}+0.5 \%\left[\mathrm{~N}_{8881}\right]\left[\mathrm{C}_{8: 0}\right]$ & $8.56 \pm 0.50$ & 5.84 & $8.62 \pm 0.87$ & 10.12 \\
\hline $\mathrm{BO}+1 \%\left[\mathrm{~N}_{8881}\right]\left[\mathrm{C}_{8: 0}\right]$ & $8.28 \pm 0.15$ & 1.82 & $8.94 \pm 1.02$ & 11.42 \\
\hline $\mathrm{BO}+2 \%\left[\mathrm{~N}_{8881}\right]\left[\mathrm{C}_{8: 0}\right]$ & $6.78 \pm 0.65$ & 9.59 & $9.05 \pm 1.57$ & 17.37 \\
\hline $\mathrm{BO}+0.5 \%\left[\mathrm{~N}_{8881}\right]\left[\mathrm{C}_{12: 0}\right]$ & $7.97 \pm 0.11$ & 1.43 & $8.3 \pm 0.72$ & 8.66 \\
\hline $\mathrm{BO}+1 \%\left[\mathrm{~N}_{8881}\right]\left[\mathrm{C}_{12: 0}\right]$ & $8.22 \pm 0.48$ & 5.84 & $8.3 \pm 0.38$ & 4.62 \\
\hline $\mathrm{BO}+2 \%\left[\mathrm{~N}_{8881}\right]\left[\mathrm{C}_{12: 0}\right]$ & $8.47 \pm 0.52$ & 6.09 & $7.64 \pm 0.74$ & 9.74 \\
\hline $\mathrm{BO}+0.5 \%\left[\mathrm{~N}_{8881}\right]\left[\mathrm{C}_{16: 0}\right]$ & $8.59 \pm 0.50$ & 5.78 & $8.84 \pm 0.63$ & 7.11 \\
\hline $\mathrm{BO}+1 \%\left[\mathrm{~N}_{8881}\right]\left[\mathrm{C}_{16: 0}\right]$ & $7.43 \pm 0.71$ & 9.56 & $7.86 \pm 0.03$ & 0.41 \\
\hline $\mathrm{BO}+2 \%\left[\mathrm{~N}_{8881}\right]\left[\mathrm{C}_{16: 0}\right]$ & $7.74 \pm 0.15$ & 1.89 & $8.40 \pm 0.56$ & 6.69 \\
\hline
\end{tabular}

\subsection{Friction properties}

The determination of the Stribeck curve for all lubricant samples were conducted at different temperatures using a Mini Traction Machine tribometer (MTM). Figs. 4-6 showed that all the ionic liquids operate under elastohydrodynamic lubrication at high speeds under all temperatures. Besides, COF results are in agreement with the ECR ones. Values close to $100 \%$ of ECR correspond to a thick lubricant film, which occurs at high speed values and under elastohydrodynamic lubrication regime. Regarding $\left[\mathrm{N}_{8881}\right]\left[\mathrm{C}_{8: 0}\right]$ samples (Fig. 4), the traction behavior was quite similar under elastohydrodynamic lubrication regime because of the viscosity of the samples are identical (Table 1). Under mixed lubrication regime (at lower speed and/or higher temperature) the friction coefficient of the mixtures does not perform better than the base oil. These traction results under mixed lubrication regime correlate with the lower ECR of the mixtures in comparison with the base oil.

On the other hand, the friction coefficient clearly increased under mixed lubrication regime with the $\left[\mathrm{N}_{8881}\right]\left[\mathrm{C}_{12: 0}\right]$ containing samples when the IL concentration rose from 0.5 to 1 and $2 \mathrm{wt} \%$ (Fig. 5), which is a result of thinner lubricant film and then an increase of the number of asperity contacts causing a quick reduction in the ECR values. In addition, the traction behavior of the $\left[\mathrm{N}_{8881}\right]\left[\mathrm{C}_{16: 0}\right]$ containing samples (Fig. 6) was similar to the $\left[\mathrm{N}_{8881}\right]\left[\mathrm{C}_{12: 0}\right]$ ones, with higher friction coefficient values of the 1 and $2 \mathrm{wt} \%$ mixtures. These results are also corresponding with the ECR values for these lubricant samples. 

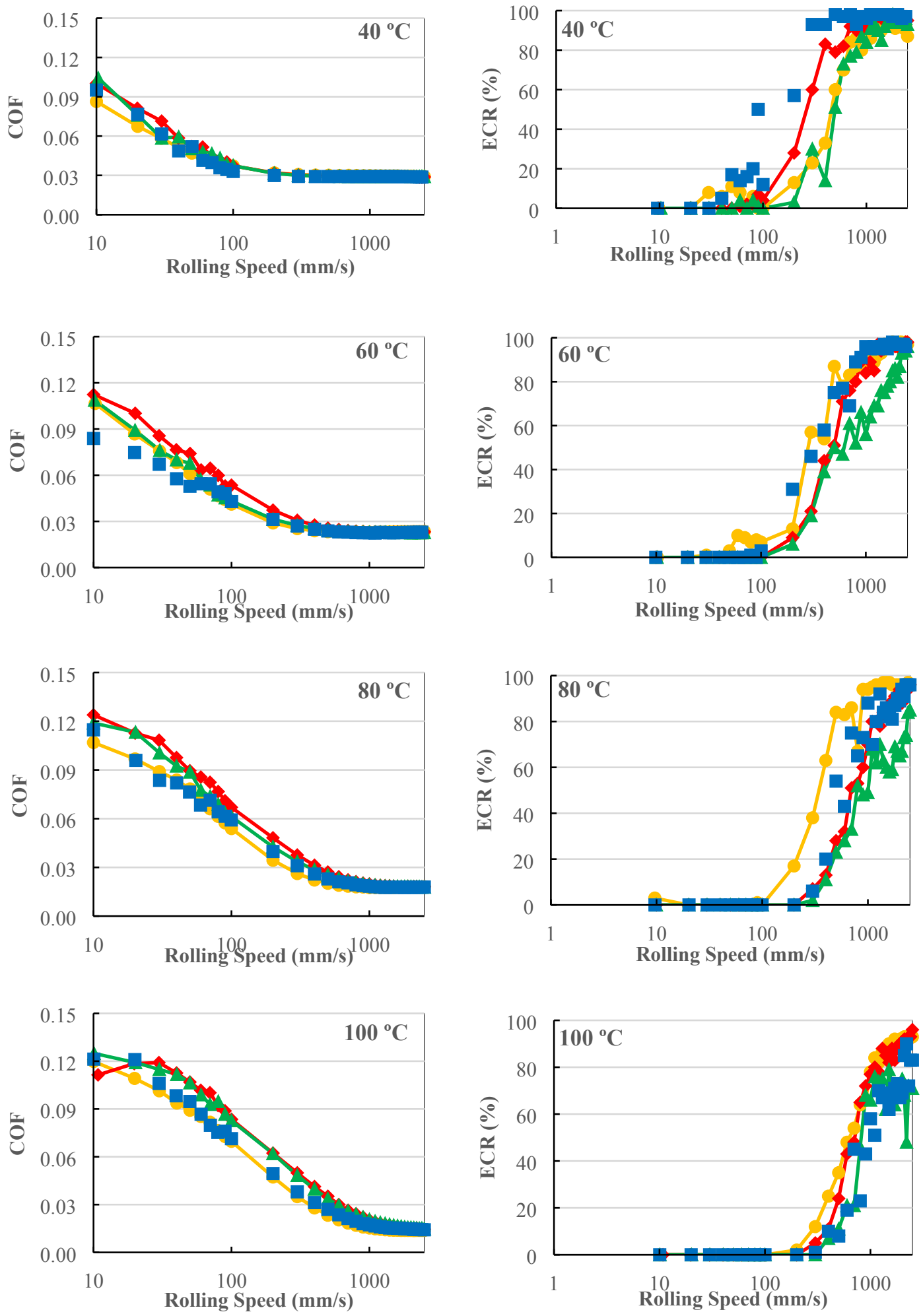

Fig. 4 Stribeck curves and electric contact resistance (ECR) of $\left[\mathrm{N}_{8881}\right]\left[\mathrm{C}_{8: 0}\right]$ containing mixtures at

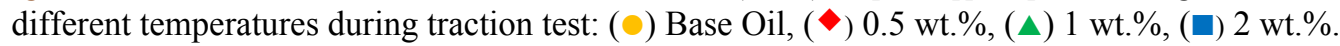



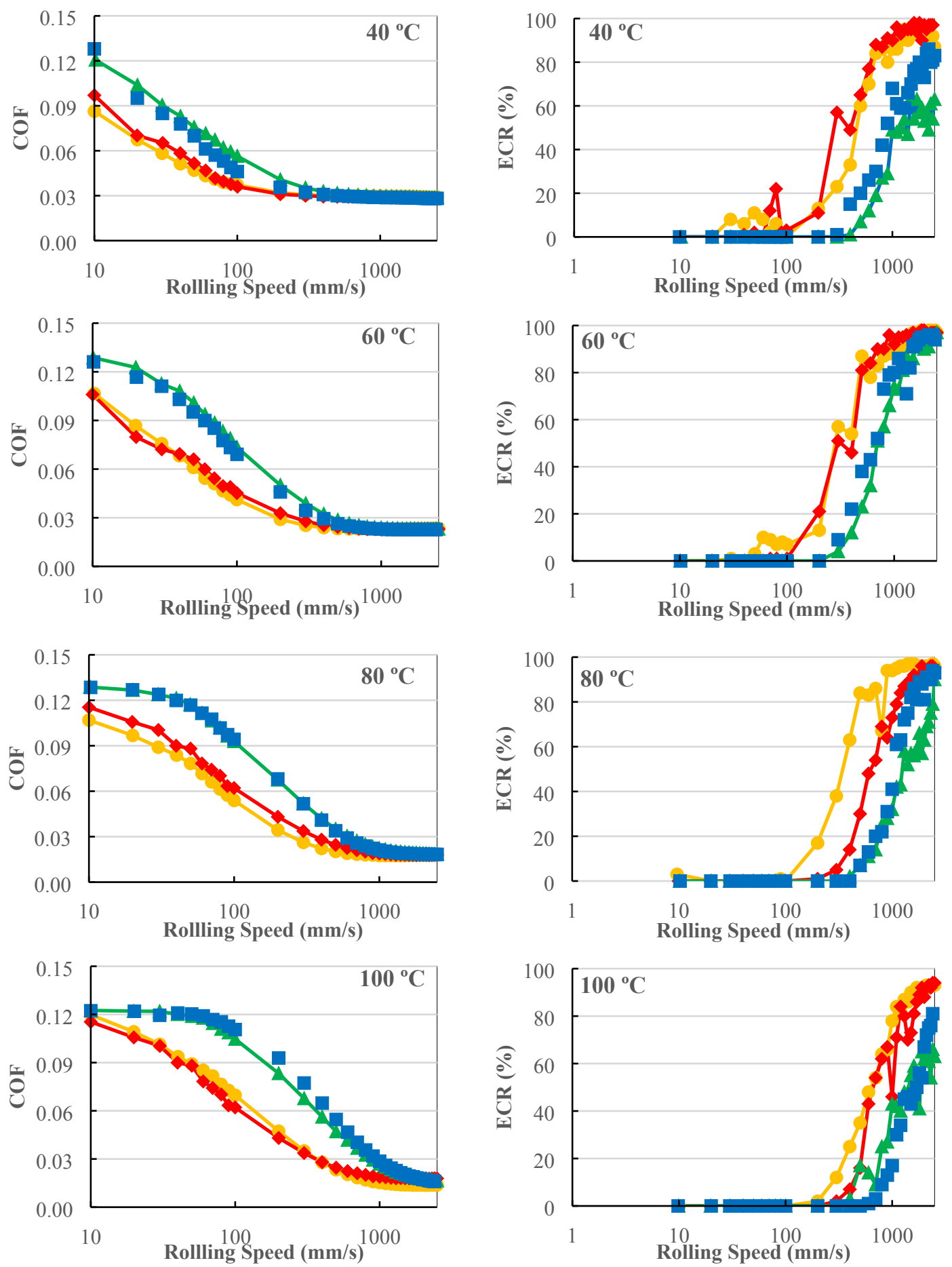

Fig. 5 Stribeck curves and electric contact resistance of $\left[\mathrm{N}_{8881}\right]\left[\mathrm{C}_{12: 0}\right]$ containing mixtures at different

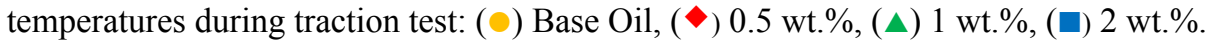



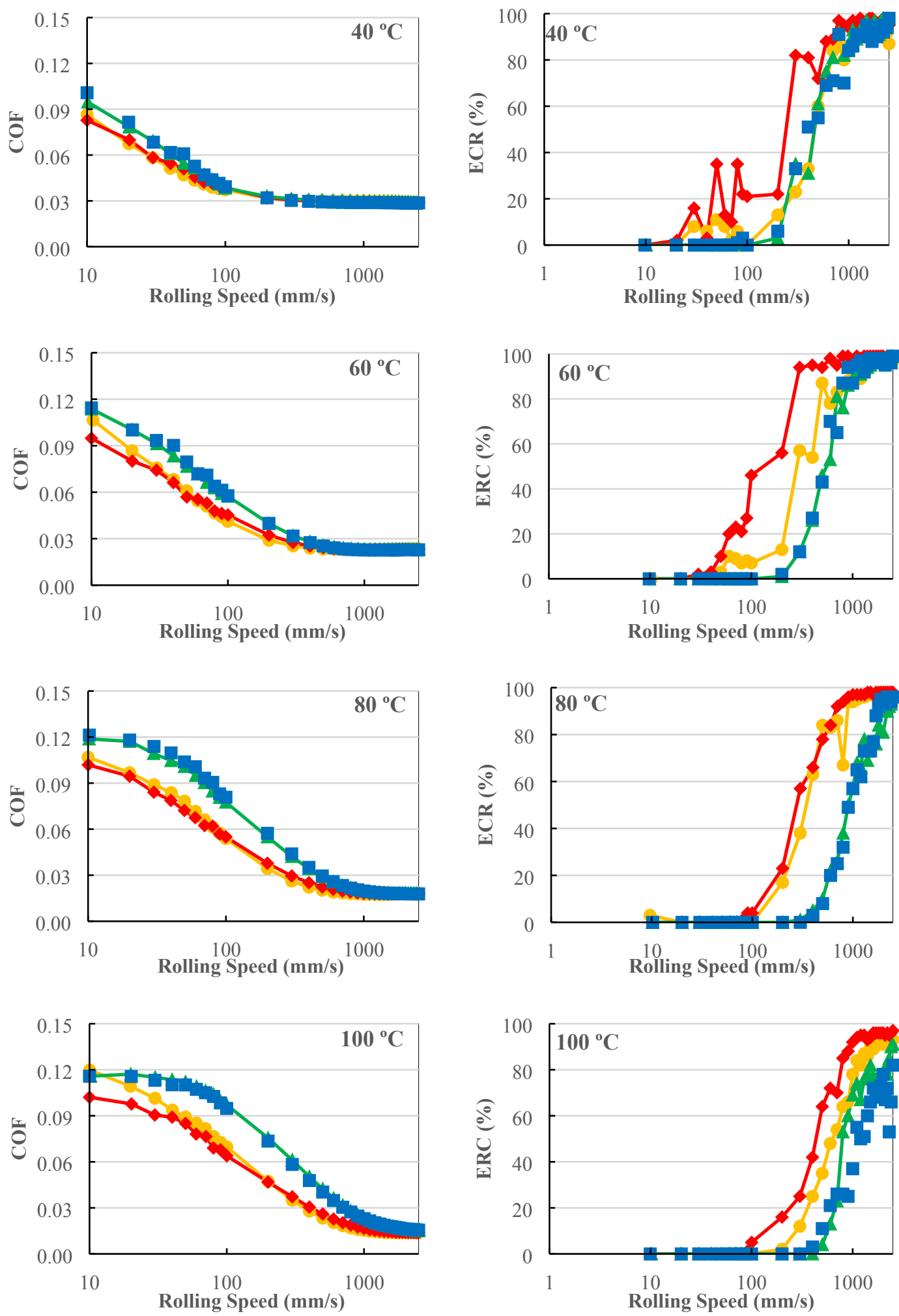

Fig. 6 Stribeck curves and electric contact resistance of $\left[\mathrm{N}_{8881}\right]\left[\mathrm{C}_{16: 0}\right]$ containing mixtures at different

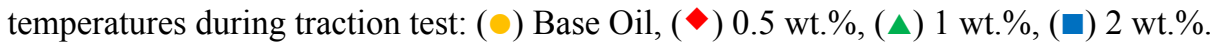


Fig. 7 shows the result of one of the 12 tests made at variable SRR with all the mixtures and the base oil at different temperatures. All the lubricant samples had similar behavior, the friction coefficient increased when the SRR varied from 5 to $50 \%$, with no significant differences between the base oil and the FAILcontaining blends.

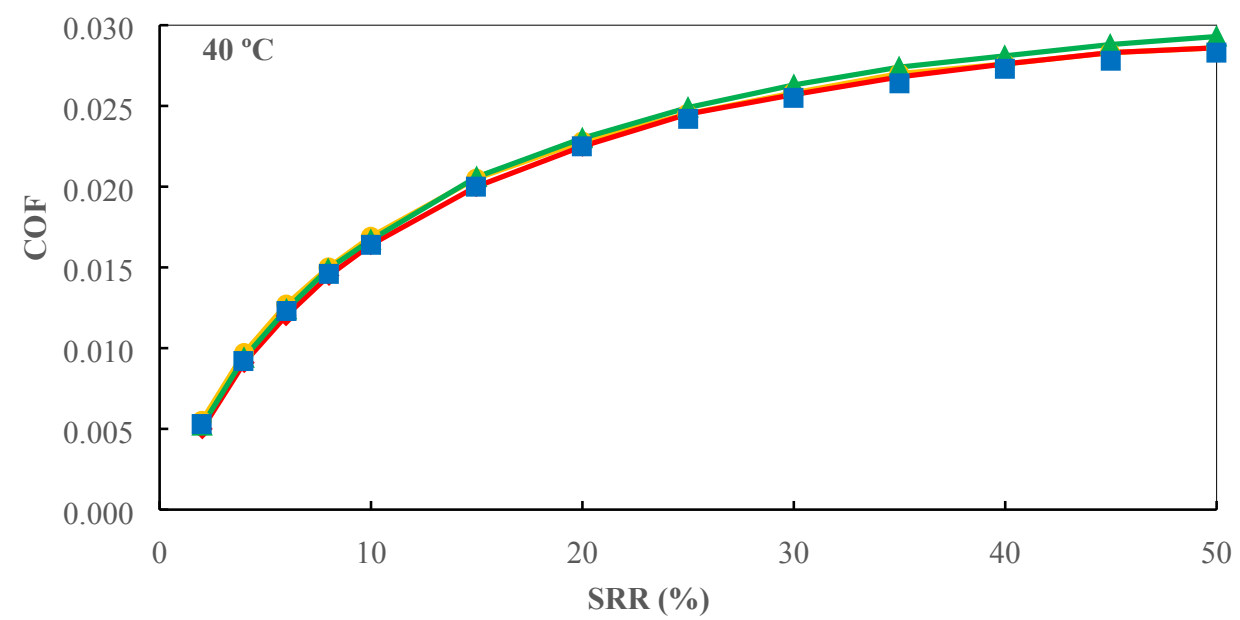

Fig. 7 SRR variable traction tests of $\left[\mathrm{N}_{8881}\right]\left[\mathrm{C}_{16: 0}\right]$ containing mixtures at $40{ }^{\circ} \mathrm{C}$ :

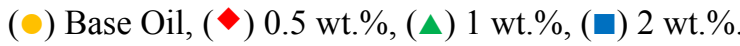

\subsection{Surface characterization}

Fig. 8 shows the SEM wear scar images at $25 \mathrm{x}$ after the sliding tests made with the IL-containing mixtures at $25^{\circ} \mathrm{C}$, and the wear scar from test made with pure base oil is shown at the bottom right at bigger size. No important changes were detected between samples from SEM images. The wear mechanism found in all samples was adhesive. In all cases, the EDX analysis attached in a table form shows that mainly the elements present in the steel disc were found on the wear scar. 


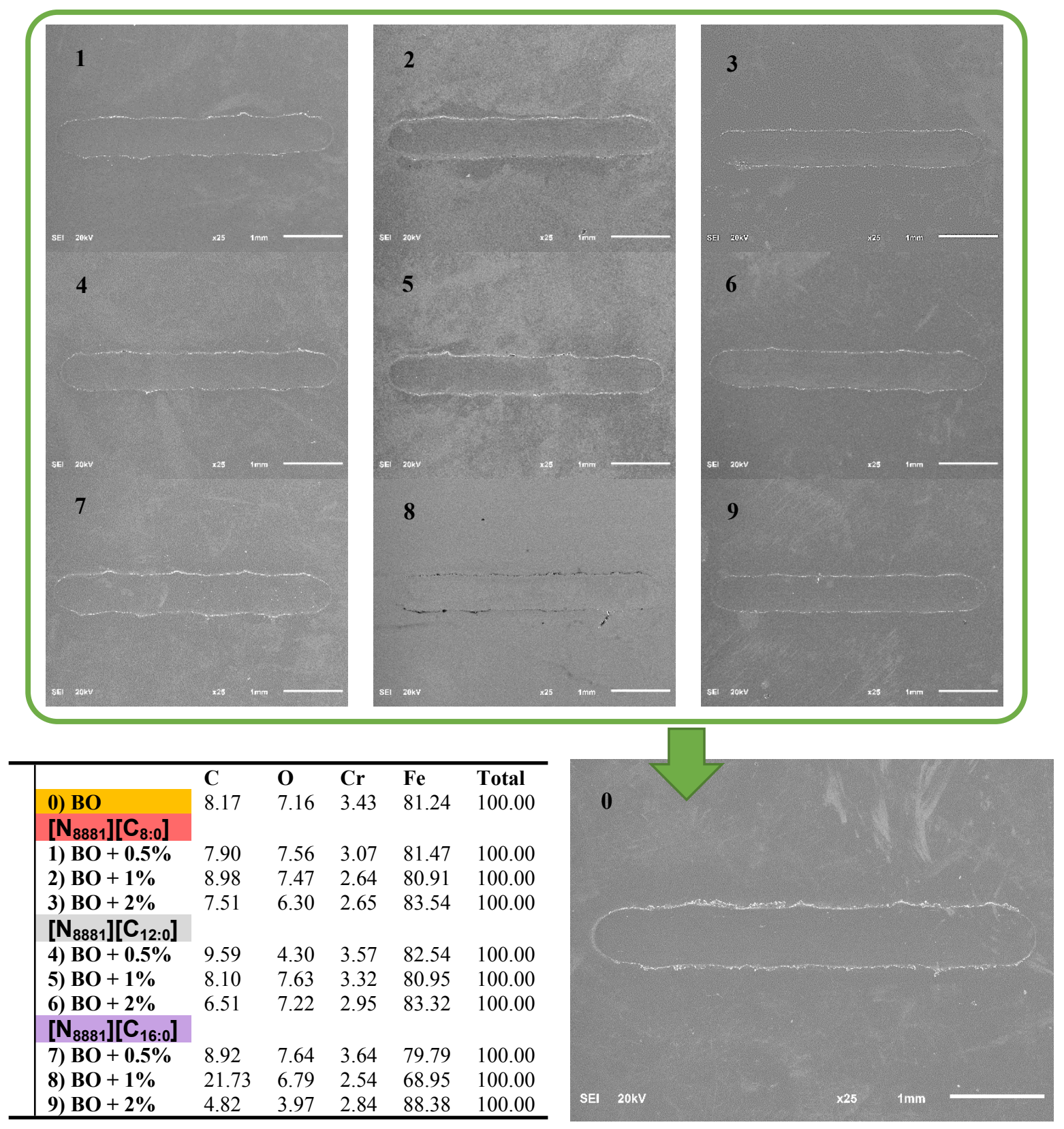

Fig. 8. SEM wear scar after tribological tests at $25^{\circ} \mathrm{C}$ and EDX element analysis in wt.\%.

In addition, Fig. 9 shows the corresponding SEM wear scar images at $25 \mathrm{x}$ for the sliding tests made at $100{ }^{\circ} \mathrm{C}$ and the wear scar image from test made with pure base oil is also shown at bigger size in the bottom right. No relevant changes between samples can be found in a similar way that corresponding samples tested at $25^{\circ} \mathrm{C}$. The wear mechanism in these cases was also adhesive. The EDX analysis is also attached in a table form in the bottom left side of the Fig. 8. 


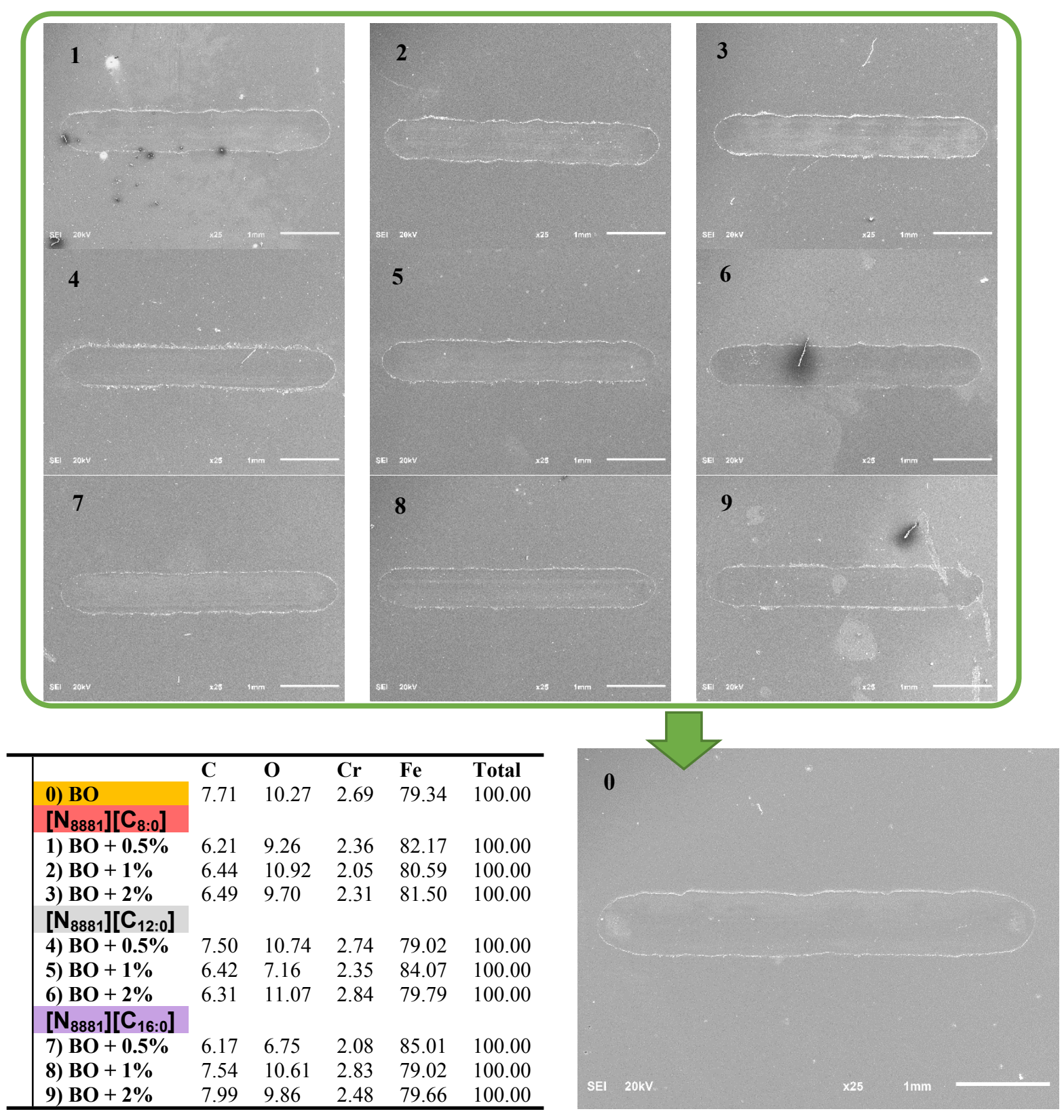

Fig. 9. SEM wear scar after tribological tests at $100{ }^{\circ} \mathrm{C}$ and EDX element analysis in wt.\%.

The surfaces analyzed by XPS exhibited similar results. Nitrogen could not be detected on the surface evidencing a poor interaction of the cation with the surface. The $\mathrm{Fe} 2 \mathrm{p}^{3 / 2}$ band and the O1s band were analyzed in high resolution mode. Curve fitting and interpretation for $\mathrm{Fe} 2 \mathrm{p}^{3 / 2}$ was carried out following the indication by Mangolini and Mayer using an exponential blend with $\mathrm{k}=0.65$ for $\mathrm{Fe}(0)$ at $707.5 \mathrm{eV}$ as well as an exponential blend with $\mathrm{k}=1.5$ for $\mathrm{Fe}$ (III) around $711 \mathrm{eV}$; the band at higher energies were assigned to $\mathrm{FeOOH}[66,67]$.

The oxygen $\mathrm{O} 1 \mathrm{~s}$ band was fitted using two curves, a first one which can be attributable to iron oxides, with the highest percentage, and a smaller one which probably comes from organic $\mathrm{C}=\mathrm{O}$, which is present in the 
fatty acid acting as anion in the ionic liquid [68]. As can be seen in Tables 3 and 4, there is almost no difference in the surface composition regarding the iron and oxygen elements for the samples assayed at $100{ }^{\circ} \mathrm{C}$. This is consistent with the friction and wear results, which also does not improve compared to the neat base oil.

Table 3. Fe $2 \mathrm{p}^{3 / 2} \mathrm{XPS}$ bands at $100{ }^{\circ} \mathrm{C}$.

\begin{tabular}{|c|c|c|c|c|c|c|}
\hline \multirow{2}{*}{ Lubricant samples } & \multicolumn{3}{|c|}{ Peak position (eV) } & \multicolumn{3}{|c|}{ Peak contribution $(\%)$} \\
\hline & $\mathrm{Fe}(0)$ & $\mathrm{Fe}(\mathrm{III})$ & $\mathrm{FeOOH}$ & $\mathrm{Fe}(0)$ & $\mathrm{Fe}(\mathrm{III})$ & $\mathrm{FeOOH}$ \\
\hline Base oil (BO) & 707.1 & 709.9 & 712.3 & 26 & 55 & 19 \\
\hline $\mathrm{BO}+0.5 \%\left[\mathrm{~N}_{8881}\right]\left[\mathrm{C}_{8: 0}\right]$ & 707.2 & 710.1 & 712.5 & 29 & 54 & 17 \\
\hline $\mathrm{BO}+0.5 \%\left[\mathrm{~N}_{8881}\right]\left[\mathrm{C}_{12: 0}\right]$ & 707.2 & 710.0 & 712.5 & 29 & 53 & 17 \\
\hline $\mathrm{BO}+0.5 \%\left[\mathrm{~N}_{8881}\right]\left[\mathrm{C}_{16: 0}\right]$ & 707.0 & 709.8 & 712.3 & 27 & 55 & 18 \\
\hline $\mathrm{BO}+1 \%\left[\mathrm{~N}_{8881}\right]\left[\mathrm{C}_{8: 0}\right]$ & 707.2 & 709.9 & 712.2 & 26 & 53 & 21 \\
\hline $\mathrm{BO}+1 \%\left[\mathrm{~N}_{8881}\right]\left[\mathrm{C}_{12: 0}\right]$ & 707.1 & 710.0 & 712.4 & 24 & 55 & 21 \\
\hline $\mathrm{BO}+1 \%\left[\mathrm{~N}_{8881}\right]\left[\mathrm{C}_{16: 0}\right]$ & 707.4 & 710.0 & 712.4 & 26 & 52 & 22 \\
\hline $\mathrm{BO}+2 \%\left[\mathrm{~N}_{8881}\right]\left[\mathrm{C}_{8: 0}\right]$ & 707.0 & 709.8 & 712.4 & 27 & 57 & 16 \\
\hline $\mathrm{BO}+2 \%\left[\mathrm{~N}_{8881}\right]\left[\mathrm{C}_{12: 0}\right]$ & 707.2 & 709.9 & 712.4 & 23 & 56 & 21 \\
\hline $\mathrm{BO}+2 \%\left[\mathrm{~N}_{8881}\right]\left[\mathrm{C}_{16: 0}\right]$ & 706.9 & 709.7 & 712.1 & 26 & 55 & 19 \\
\hline
\end{tabular}

Table 4. O 1s XPS bands at $100^{\circ} \mathrm{C}$.

\begin{tabular}{lccccc}
\hline \multirow{2}{*}{ Lubricant samples } & \multicolumn{2}{c}{ Peak position (eV) } & & \multicolumn{2}{c}{ Peak contribution (\%) } \\
\cline { 2 - 3 } \cline { 5 - 6 } & $\mathrm{Fe}(\mathrm{OH}) \mathrm{O}+\mathrm{Fe}_{2} \mathrm{O}_{3}$ & $\mathrm{C}=\mathrm{O}$ & & $\mathrm{Fe}(\mathrm{OH}) \mathrm{O}+\mathrm{Fe}_{2} \mathrm{O}_{3}$ & $\mathrm{C}=\mathrm{O}$ \\
\hline Base oil $(\mathrm{BO})$ & 529.9 & 532.3 & & 80 & 20 \\
\hline $\mathrm{BO}+0.5 \%\left[\mathrm{~N}_{8881}\right]\left[\mathrm{C}_{8: 0}\right]$ & 529.9 & 532.4 & & 74 & 26 \\
$\mathrm{BO}+0.5 \%\left[\mathrm{~N}_{8881}\right]\left[\mathrm{C}_{12: 0}\right]$ & 529.9 & 532.6 & & 80 & 20 \\
$\mathrm{BO}+0.5 \%\left[\mathrm{~N}_{8881}\right]\left[\mathrm{C}_{16: 0}\right]$ & 529.8 & 532.5 & & 73 & 27 \\
\hline $\mathrm{BO}+1 \%\left[\mathrm{~N}_{8881}\right]\left[\mathrm{C}_{8: 0}\right]$ & 529.9 & 532.5 & & 74 & 26 \\
$\mathrm{BO}+1 \%\left[\mathrm{~N}_{8881}\right]\left[\mathrm{C}_{12: 0}\right]$ & 530.1 & 532.8 & & 81 & 19 \\
$\mathrm{BO}+1 \%\left[\mathrm{~N}_{8881}\right]\left[\mathrm{C}_{16: 0}\right]$ & 530.0 & 532.4 & & 73 & 27 \\
\hline $\mathrm{BO}+2 \%\left[\mathrm{~N}_{8881}\right]\left[\mathrm{C}_{8: 0}\right]$ & 529.7 & 532.3 & & 70 & 30 \\
$\mathrm{BO}+2 \%\left[\mathrm{~N}_{8881}\right]\left[\mathrm{C}_{12: 0}\right]$ & 530.0 & 532.6 & & 63 & 37 \\
$\mathrm{BO}+2 \%\left[\mathrm{~N}_{8881}\right]\left[\mathrm{C}_{16: 0}\right]$ & 529.7 & 532.4 & & 58 & 42 \\
\hline
\end{tabular}

According to the results shown in Tables 5 and 6 , the samples assayed at $25^{\circ} \mathrm{C}$ show a higher amount of $\mathrm{C}=\mathrm{O}$ signal in the $\mathrm{O} 1 \mathrm{~s}$ peak, which is attributable to the ionic liquid. The presence of this band of the ionic liquid suggest a physical interaction which might be correlated to the better wear features obtained when working at room temperature. On the contrary, the iron signal does not seem to be affected by either the concentration or the nature of the ionic liquid, showing a very similar Fe $2 \mathrm{p}^{3 / 2}$ spectrum in every case. 
Table 5. Fe $2 \mathrm{p}^{3 / 2}$ XPS bands at $25^{\circ} \mathrm{C}$.

\begin{tabular}{|c|c|c|c|c|c|c|}
\hline \multirow{2}{*}{ Lubricant samples } & \multicolumn{3}{|c|}{ Peak position (eV) } & \multicolumn{3}{|c|}{ Peak contribution $(\%)$} \\
\hline & $\mathrm{Fe}(0)$ & $\mathrm{Fe}(\mathrm{III})$ & $\mathrm{FeOOH}$ & $\mathrm{Fe}(0)$ & $\mathrm{Fe}(\mathrm{III})$ & $\mathrm{FeOOH}$ \\
\hline Base oil (BO) & 707.6 & 710.1 & 712.2 & 21 & 55 & 24 \\
\hline $\mathrm{BO}+0.5 \%\left[\mathrm{~N}_{8881}\right]\left[\mathrm{C}_{8: 0}\right]$ & 707.4 & 710.1 & 712.4 & 29 & 53 & 18 \\
\hline $\mathrm{BO}+0.5 \%\left[\mathrm{~N}_{8881}\right]\left[\mathrm{C}_{12: 0}\right]$ & 707.3 & 710 & 712.5 & 26 & 55 & 18 \\
\hline $\mathrm{BO}+0.5 \%\left[\mathrm{~N}_{8881}\right]\left[\mathrm{C}_{16: 0}\right]$ & 707.2 & 710 & 712.4 & 34 & 49 & 18 \\
\hline $\mathrm{BO}+1 \%\left[\mathrm{~N}_{8881}\right]\left[\mathrm{C}_{8: 0}\right]$ & 707.8 & 710.3 & 712.5 & 32 & 47 & 21 \\
\hline $\mathrm{BO}+1 \%\left[\mathrm{~N}_{8881}\right]\left[\mathrm{C}_{12: 0}\right]$ & 707.2 & 710 & 712.2 & 28 & 49 & 23 \\
\hline $\mathrm{BO}+1 \%\left[\mathrm{~N}_{8881}\right]\left[\mathrm{C}_{16: 0}\right]$ & 707.3 & 710 & 712.4 & 34 & 47 & 19 \\
\hline $\mathrm{BO}+2 \%\left[\mathrm{~N}_{8881}\right]\left[\mathrm{C}_{8: 0}\right]$ & 707.4 & 710.2 & 712.7 & 29 & 56 & 15 \\
\hline $\mathrm{BO}+2 \%\left[\mathrm{~N}_{8881}\right]\left[\mathrm{C}_{12: 0}\right]$ & 707.3 & 710.1 & 712.5 & 23 & 54 & 23 \\
\hline $\mathrm{BO}+2 \%\left[\mathrm{~N}_{8881}\right]\left[\mathrm{C}_{16: 0}\right]$ & 707.5 & 710.1 & 712.5 & 30 & 54 & 16 \\
\hline
\end{tabular}

Table 6. O 1s XPS bands at $25^{\circ} \mathrm{C}$.

\begin{tabular}{lccccc}
\hline \multirow{2}{*}{ Lubricant samples } & \multicolumn{2}{c}{ Peak position (eV) } & & \multicolumn{2}{c}{ Peak contribution (\%) } \\
\cline { 2 - 3 } \cline { 5 - 6 } & $\mathrm{Fe}(\mathrm{OH}) \mathrm{O}+\mathrm{Fe}_{2} \mathrm{O}_{3}$ & $\mathrm{C}=\mathrm{O}$ & & $\mathrm{Fe}(\mathrm{OH}) \mathrm{O}+\mathrm{Fe}_{2} \mathrm{O}_{3}$ & $\mathrm{C}=\mathrm{O}$ \\
\hline Base oil $(\mathrm{BO})$ & 530.1 & 532.4 & & 66 & 34 \\
\hline $\mathrm{BO}+0.5 \%\left[\mathrm{~N}_{8881}\right]\left[\mathrm{C}_{8: 0}\right]$ & 530.1 & 532.7 & & 62 & 38 \\
$\mathrm{BO}+0.5 \%\left[\mathrm{~N}_{8881}\right]\left[\mathrm{C}_{12: 0}\right]$ & 529.9 & 532.6 & & 68 & 32 \\
$\mathrm{BO}+0.5 \%\left[\mathrm{~N}_{8881}\right]\left[\mathrm{C}_{16: 0}\right]$ & 529.8 & 532.3 & & 69 & 31 \\
\hline $\mathrm{BO}+1 \%\left[\mathrm{~N}_{8881}\right]\left[\mathrm{C}_{8: 0}\right]$ & 530.2 & 532.4 & & 59 & 41 \\
$\mathrm{BO}+1 \%\left[\mathrm{~N}_{8881}\right]\left[\mathrm{C}_{12: 0}\right]$ & 530 & 532.4 & & 66 & 34 \\
$\mathrm{BO}+1 \%\left[\mathrm{~N}_{8881}\right]\left[\mathrm{C}_{16: 0}\right]$ & 529.9 & 532.6 & & 74 & 26 \\
\hline $\mathrm{BO}+2 \%\left[\mathrm{~N}_{8881}\right]\left[\mathrm{C}_{8: 0}\right]$ & 530.1 & 532.7 & & 66 & 34 \\
$\mathrm{BO}+2 \%\left[\mathrm{~N}_{8881}\right]\left[\mathrm{C}_{12: 0}\right]$ & 530.3 & 532.6 & & 61 & 39 \\
$\mathrm{BO}+2 \%\left[\mathrm{~N}_{8881}\right]\left[\mathrm{C}_{16: 0}\right]$ & 529.8 & 532.4 & & 54 & 46 \\
\hline
\end{tabular}

\section{Conclusions}

A novel family of ionic liquids synthesized from fatty acids have been studied in this research as lubricant additive in a base oil (ester) in three different concentrations. The following conclusions can be drawn from the results obtained:

- The use of these ionic liquids as an additive in concentrations of $0.5,1$ and $2 \mathrm{wt} \%$ hardly changes the density, viscosity and viscosity index of the base oil.

- The samples obtained by mixing the ionic liquids with the base oil showed excellent stability for at least 14 days.

- The antifriction and antiwear performance of the base oil was improved at room temperature with the addition of the three different FAILs in three different concentrations, but this performance 
was not found at temperature of $100{ }^{\circ} \mathrm{C}$ probably because of the moderate thermal stability of the fatty-acid ionic liquids.

- All the samples behaved similarly under elastohydrodynamic lubrication at fixed SRR value because of their similar viscosity. However, under mixed lubrication regime, the pure base oil and the mixtures with 0.5 wt.\% of the corresponding IL behaved better that the rest of lubricant samples. In addition, no significant differences were found between the base oil and the FAIL mixtures in the variable SRR tests.

- The EDX analysis showed mainly the elements present in the steel disc and the wear mechanism found in all cases regardless the temperature was adhesive.

- The signal from oxygen in XPS show a slightly higher amount of $\mathrm{C}=\mathrm{O}$ bond attributable to the ionic liquid on the wear scar after reciprocating tests at $25^{\circ} \mathrm{C}$ than that at $100{ }^{\circ} \mathrm{C}$. This presence can be correlated to the better antiwear behavior.

\section{Acknowledgments}

The authors would like to thank to the Spanish Ministry of Economy and Competitiveness and the Foundation for the Promotion of Applied Scientific Research and Technology in Asturias (FICYT) for supporting this research under the framework of the projects FAILs_LUBEs (DPI2016-79690-R), LUBNANOsensII (MAT2015-66747-R) and LuSuTec (IDI/2018/000131), respectively. The Emulsions and Interfacial Phenomena research group from University of Oviedo is also acknowledged.

\section{References}

[1] P. Wassercheid, T. Welton, Ionic liquid in synthesis, second ed., Wiley-Vch, 2008.

[2] F. Zhou, Y. Liang, W. Liu, Ionic liquid lubricants: designed chemistry for engineering applications, Chem. Soc. Rev. 38 (2009) 2590-2599. https://doi.org/10.1039/ b817899m.

[3] Y. Zhou, J. Qu, Ionic liquids as lubricant additives - a review, ACS Appl Mater Interfaces, 9(4) (2016) 3209-3222. https://doi.org/10.1021/acsami.6b12489.

[4] F. Guo, S. Zhang, J. Wang, B. Teng, T. Zhang, M. Fan, Synthesis and applications of ionic liquids in clean energy and environment: a review, Curr. Org. Chem. 19(5) (2015) 455-468. https://doi.org/10.2174/1385272819666150114235649.

[5] S.A.S. Amiril, E.A. Rahim, S. Syahrullail, A review on ionic liquids as sustainable lubricants in manufacturing and engineering: recent research, performance, and applications, J. Clean. Prod. 168 (2016) 1571-1589. https://doi.org/10.1016/j.jclepro.2017.03.197.

[6] A. Berthod, M.J. Ruiz-Ángel, S. Carda-Broch, Recent advances on ionic liquid uses in separation techniques, J. Chromatogr. A. 1559 (2018) 2-16. https://doi.org/10.1016/j.chroma.2017.09.044.

[7] H. Liu, H. Yu, Ionic liquids for electrochemical energy storage devices applications, J. Mater. Sci. Technol. 35 (2019) 674-86. https://doi.org/10.1016/j.jmst.2018.10.007. 
[8] Z. Ullah, A.S. Khan, N. Muhammad, R. Ullah, A.S. Alqahtani, S.N. Shah, O.B. Ghanem, M.A. Bustam, Z. Man, A review on ionic liquids as perspective catalysts in transesterification of different feedstock oil into biodiesel, J. Mol. Liq. $266 \quad$ (2018) 673-686. https://doi.org/10.1016/j.molliq.2018.06.024.

[9] M. Aghaie, N. Rezaei, S. Zendehboudi, A systematic review on CO2 capture with ionic liquids: current status and future prospects, Renew. Sustain. Energy Rev. 96 (2018) 502-25. https://doi.org/10.1016/j.rser.2018.07.004.

[10] L.Y. Wang, Q.J. Guo, M.S. Lee, Recent advances in metal extraction improvement: mixture systems consisting of ionic liquid and molecular extractant, Sep. Purif. Technol. 210 (2019) 292-303. https://doi.org/10.1016/j.seppur.2018.08.016.

[11] F. Javed, F. Ullah, M.R. Zakaria, H.M. Akil, An approach to classification and hi-tech applications of room-temperature ionic liquids (RTILs): a review, J. Mol. Liq. 271 (2018) 403-420. https://doi.org/10.1016/j.molliq.2018.09.005.

[12] C. Ye, W. Liu, Y. Chen, and L. Yu, Room-temperature ionic liquids: a novel versatile lubricant, Chem. Commun. 21 (2001) 2244-2245. https://doi.org/10.1039/B106935G.

[13] S. Stolte, S. Steudte, O. Areitioaurtena, F. Pagano, J. Thoming, P. Stepnowski, A. Igartua, Ionic liquids as lubricants or lubrication additives: an ecotoxicity and biodegradability assessment, Chemosphere 89(9) (2012) 1135-1141. https://doi.org/10.1016/j.chemosphere.2012.05.102.

[14] P. Oulego, D. Blanco, D. Ramos, J.L. Viesca, M. Díaz, A. Hernández Battez, Environmental properties of phosphonium, imidazolium and ammonium cation-based ionic liquids as potential lubricant additives, J. Mol. Liq. 272 (2018) 937-947. https://doi.org/10.1016/j.molliq.2018.10.106.

[15] G.V.S.M. Carrera, C.A.M. Afonso, L.C. Branco, Interfacial properties, densities, and contact angles of task specific ionic liquids, J. Chem. Eng. Data 55 (2010) 609-615. https://doi.org/10.1021/je900502s.

[16] R. Alcalde, G. García, M. Atilhan, S. Aparicio, Systematic study on the viscosity of ionic liquids: measurement and prediction, Ind. Eng. Chem. Res. 54(43) (2015) 10918-10924. https://doi.org/ 10.1021/acs.iecr.5b02713.

[17] H. Shirota, T. Mandai, H. Fukazawa, T. Kato, Comparison between dicationic and monocationic ionic liquids: liquid density, thermal properties, surface tension, and shear viscosity, J. Chem. Eng. Data 56 (2011) 2453-2459. https://doi.org/10.1021/je2000183.

[18] X. Zhang, F. Huo, X. Liu, K. Dong, H. He, X. Yao, S. Zhang, Influence of microstructure and interaction on viscosity of ionic liquids, Ind. Eng. Chem. Res. 54 (2015) 3505-3514. https://doi.org/10.1021/acs.iecr.5b00415.

[19] A. Hernández Battez, M. Bartolomé, D. Blanco, J.L. Viesca, A. Fernández-González, R. González, Phosphonium cation-based ionic liquids as neat lubricants: physicochemical and tribological performance, Tribol. Int. 95 (2016) 118-131. https://doi.org/10.1016/j.triboint.2015.11.015.

[20] R. González, M. Bartolomé, D. Blanco, J.L. Viesca, A. Fernández-González, A.H. Battez, Effectiveness of phosphonium cation-based ionic liquids as lubricant additive, Tribol. Int. 98 (2016) 82-93. https://doi.org/10.1016/j.triboint.2016.02.016.

[21] B. Yu, D.G. Bansal, J. Qu, X. Sun, H. Luo, S. Dai, D.J. Smolenski, Oil-miscible and non-corrosive phosphonium-based ionic liquids as candidate lubricant additives, Wear 289 (2012) 58-64. https://doi.org/10.1016/j.wear.2012.04.015.

[22] V. Totolin, I. Minami, C. Gabler, J. Brenner, N. Dörr, Lubrication mechanism of phosphonium phosphate ionic liquid additive in alkylborane-imidazole complexes, Trib. Lett. 53(2) (2014) 421-432. https://doi.org/10.1007/s11249-013-0281-0.

[23] I. Otero, E.R. López, M. Reichelt, M. Villanueva, J. Salgado, J. Fernández, Ionic liquids based on phosphonium cations as neat lubricants or lubricant additives for a steel/steel contact. ACS Appl. Mater. Interfaces 6(15) (2014) 13115-13128. https://doi.org/10.1021/am502980m.

[24] A.E. Jiménez, M.D. Bermúdez, F.J. Carrión, G. Martínez-Nicolás, Room temperature ionic liquids as lubricant additives in steel-aluminium contacts: influence of sliding velocity, normal load and temperature, Wear 261(3-4) (2006) 347-359. https://doi.org/10.1016/j.wear.2005.11.004.

[25] D. Blanco, A.H. Battez, J.L. Viesca, R. González, A. Fernández-González, Lubrication of CrN coating 
with ethyl-dimethyl-2-methoxyethylammonium tris(pentafluoroethyl)trifluorophosphate ionic liquid as additive to PAO 6, Tribol. Lett. 41 (2011) 295-302. https://doi.org/10.1007/s11249-010-9714-1.

[26] D. Blanco, R. González, A. Hernández Battez, J.L. Viesca, A. Fernández-González, Use of ethyldimethyl-2-methoxyethylammonium tris(pentafluoroethyl) trifluorophosphate as base oil additive in the lubrication of TiN PVD coating, Tribol. Int. 44 (2011) 645-650. https://doi.org/10.1016/j.triboint.2011.01.004.

[27] A. Westerholt, M. Weschta, A. Bösmann, S. Tremmel, Y. Korth, M. Wolf, P. Wasserscheid, Halidefree synthesis and tribological performance of oil-miscible ammonium and phosphonium-based ionic liquids. ACS Sustainable Chem. Eng. 3(5) (2015) 797-808. https://doi.org/10.1021/sc500517n.

[28] J. Qu, H.M. Luo, M.F. Chi, C. Ma, P.J. Blau, S. Dai, M.B. Viola, Comparison of an oil-miscible ionic liquid and ZDDP as a lubricant anti-wear additive, Tribol. Int. 71 (2014) 88-97. https://doi.org/10.1016/j.triboint.2013.11.010.

[29] J. Qu, J.J. Truhan Jr., S. Dai, H. Luo, P.J. Blau, Ionic liquids with ammonium cations as lubricants or additives, Tribol. Lett. 22 (2006) 207-214. https://doi.org/10.1007/s11249-006-9081-0.

[30] A. Hernández Battez, C.M.C.G. Fernandes, R.C. Martins, M. Bartolomé, R. González, J.H.O. Seabra, Two phosphonium cation-based ionic liquids used as lubricant additive. Part I: film thickness and $\begin{array}{llllll}\text { friction } & \text { characteristics, } & \text { Tribol. } & \text { Int. } & 107 & \text { (2017) }\end{array}$ https://doi.org/10.1016/j.triboint.2016.10.048.

[31] A. Hernández Battez, C.M.C.G. Fernandes, R.C. Martins, B.M. Graça, M. Anand, C. Blanco, J.H.O. Seabra, Two phosphonium cation-based ionic liquids used as lubricant additive. Part II: tribofilm analysis and friction torque loss in cylindrical roller thrust bearings at constant temperature. Tribol. Int. 109 (2017) 496-504. https://doi.org/10.1016/j.triboint.2017.01.020.

[32] G. Guangteng, H. Spikes, Fractionation of liquid lubricants at solid surfaces, Wear 200(1-2) (1996) 336-345. https://doi.org/10.1016/S0043-1648(96)07268-7.

[33] J.E. Fernández Rico, A. Hernández Battez, D. García Cuervo, Wear prevention characteristics of binary oil mixtures, Wear 253 (2002) 827-831. https://doi.org/10.1016/S0043-1648(02)00229-6.

[34] A. Cambiella, J.M. Benito, C. Pazos, J. Coca, A. Hernández, J.E. Fernández, Formulation of emulsifiable cutting fluids and extreme pressure behaviour, J. Mater. Process. Technol. 184 (2007) 139-145. https://doi.org/10.1016/j.jmatprotec.2006.11.014.

[35] M. Kronberger, V. Pejakovic, C. Gabler, M. Kalin, How anion and cation species influence the tribology of a green lubricant based on ionic liquids, Proc. Inst. Mech. Eng., Part J 226 (2012) 933951. https://doi.org/10.1177/1350650112459012.

[36] Jiménez, A.E., Bermúdez, M.D.: Short alkyl chain imidazolium ionic liquid additives in lubrication of three aluminium alloys with synthetic ester oil. Tribol.-Mater., Surf. Interfaces 6 (2012) 109-115 (2012). https://doi.org/10.1179/1751584X12Y.0000000011.

[37] A.E. Somers, B. Khemchandani, P.C. Howlett, J.Z. Sun, D.R. MacFarlane, M. Forsyth, Ionic liquids as antiwear additives in base oils: influence of structure on miscibility and antiwear performance for steel on aluminum. ACS Appl. Mater. Interfaces 5 (2013) 11544-11553. https://doi.org/10.1021/am4037614.

[38] M.R. Cai, Y.M. Liang, F. Zhou, W.M. Liu, A novel imidazolium salt with antioxidation and anticorrosion dual functionalities as the additive in poly(ethylene glycol) for steel/steel contacts, Wear 306 (2013) 197-208. https://doi.org/10.1016/j.wear.2012.09.001.

[39] B. Khemchandani, A. Somers, R. Howlett, A.K. Jaiswal, E. Sayanna, M. Forsyth, A biocompatible ionic liquid as an antiwear additive for biodegradable lubricants, Tribol. Int. 77 (2014) 171-177. https://doi.org/10.1016/j.triboint.2014.04.016.

[40] D. Qiao, H.Z. Wang, D.P. Feng, Tribological performance and mechanism of phosphate ionic liquids as additives in three base oils for steel-on-aluminum contact, Tribol. Lett. 55 (2014), 517-531. https://doi.org/10.1007/s11249-014-0377-1.

[41] R. Gusain, P. Gupta, S. Saran, O.P. Khatri, Halogen-free bis(imidazolium)/bis(ammonium) di[bis(salicylato)borate] ionic liquids as energy-efficient and environmentally friendly lubricant additives, ACS Appl. Mater. Interfaces 6 (2014) 15318-15328. https://doi.org/10.1021/am503811t.

[42] L. Zhu, Q. Zhao, X. Wu, G. Zhao, X. Wang, A novel phosphate ionic liquid plays dual role in synthetic 
ester oil: from synthetic catalyst to anti-wear additive, Tribol. Int. 97 (2016) 192-199. https://doi.org/10.1016/j.triboint.2015.12.047.

[43] V. Pejaković, C. Tomastik, N. Dörr, M. Kalin, Influence of concentration and anion alkyl chain length on tribological properties of imidazolium sulfate ionic liquids as additives to glycerol in steel-steel contact lubrication, Tribol. Int. 97 (2016) 234-243. https://doi.org/10.1016/j.triboint.2016.01.034.

[44] D. Blanco, R. González, J.L. Viesca, A. Fernández-González, M. Bartolomé, A. Hernández Battez, Antifriction and antiwear properties of an ionic liquid with fluorine-containing anion used as lubricant additive, Tribol Lett 65(66) (2017). https://doi.org/10.1007/s11249-017-0846-4.

[45] J. Qu, D.G. Bansal, B. Yu, J.Y. Howe, H.M. Luo, S. Dai, H.Q. Li, P.J. Blau, B.G. Bunting, G. Mordukhovich, D.J. Smolenski, Antiwear performance and mechanism of an oil-miscible ionic liquid as a lubricant additive, ACS Appl. Mater. Interfaces 4 (2012) 997-1002. https://doi.org/10.1021/am201646k.

[46] V. Sharma, C. Gabler, N. Doerr, P.B. Aswath, Mechanism of tribofilm formation with P and S containing ionic liquids. Tribology International, $92 \quad$ (2015) 353-364. https://doi.org/10.1016/j.triboint.2015.07.009.

[47] R. Monge, R. González, A. Hernández Battez, A. Fernández-González, J.L. Viesca, A. García, M. Hadfield, Ionic liquids as an additive in fully formulated wind turbine gearbox oils, Wear 328-329 (2015) 50-63. https://doi.org/10.1016/j.wear.2015.01.041.

[48] J. Sanes, M.D. Avilés, N. Saurín, T. Espinosa, F.J. Carrión, M.D. Bermúdez, Synergy between graphene and ionic liquid lubricant additives, Trib. Int. 116 (2017) 371-382. https://doi.org/10.1016/j.triboint.2017.07.030.

[49] A. Khan, R. Gusain, O.P. Khatri, Organophosphate anion based low viscosity ionic liquids as oilmiscible additives for lubrication enhancement, J. Mol. Liq. 272 (2018) 430-438. https://doi.org/10.1016/j.molliq.2018.09.113.

[50] V. Sharma, N. Dörr, A. Erdemir, P.B. Aswath, Antiwear properties of binary ashless blend of phosphonium ionic liquids and borate esters in partially formulated oil (no Zn), Trib. Lett. 67(42) (2019). https://doi.org/10.1007/s11249-019-1152-0.

[51] G. Huang, Q. Yu, Z. Ma, M. Cai, W. liu, Probing the lubricating mechanism of oil-soluble ionic liquids additives, Tribol. Int. 107 (2017) 152-162. https://doi.org/10.1016/j.triboint.2016.08.027.

[52] V. Totolin, I. Minami, C. Gabler, N. Dörr, Halogen-free borate ionic liquids as novel lubricants for tribological applications, Trib. Int. 67 (2013) 191-198. https://doi.org/10.1016/j.triboint.2013.08.002.

[53] R. Gusain, O.P. Khatri, Halogen-free ionic liquids: effect of chelated orthoborate anion structure on their lubrication properties. RSC Adv. 5 (2015) 25287-25294. https://doi.org/10.1039/c5ra03092g.

[54] D. Blanco, N. Rivera, P. Oulego, M. Díaz, R. González, A.H. Battez, Novel fatty acid anion-based ionic liquids: contact angle, surface tension, polarity fraction and spreading parameter, J. Mol. Liq. 288 (2019) 110995. https://doi.org/10.1016/j.molliq.2019.110995.

[55] M. Smiglak, A. Metlen, R.D. Rogers, Second evolution of ionic liquids: from solvents and separations to advanced materials - energetic, Acc. Chem. Res. 40(11) (2007) 1182-1192. https://doi.org/10.1021/ar7001304.

[56] S.P.F. Costa, A.M.O. Azevedo, P.CA. G. Pinto, M.L.M.F.S. Saraiva, Environmental impact of ionic liquids: recent advances in (eco)toxicology and (bio)degradability, Chem. Sus. Chem. 10(10) (2017) 2321-2347. https://doi.org/10.1002/cssc.201700261.

[57] D. Parmentier, S.J. Metz, M.C. Kroon, Tetraalkylammonium oleate and linoleate based ionic liquids: promising extractants for metal salts, Green Chem. 15(1) (2013) 205-209. https://doi.org/10.1039/C2GC36458A.

[58] R. Gusain, S. Dhingra, O.P. Khatri, Fatty-acid-constituted halogen-free ionic liquids as renewable, environmentally friendly, and high-performance lubricant additives, Ind. Eng. Chem. Res. 55(4) (2016) 856-865. https://doi.org/10.1021/acs.iecr.5b03347.

[59] R. Gusain O.P. Khatri, Fatty acid ionic liquids as environmentally friendly lubricants for low friction and wear, RSC Adv. 6(5) (2016) 3462-3469. https://doi.org/10.1039/C5RA25001C.

[60] A.H. Battez, N. Rivera, D. Blanco, P. Oulego, J.L. Viesca, R. González, Physicochemical, traction 
and tribofilm formation properties of three octanoate-, laurate- and palmitate-anion based ionic liquids, J. Mol. Liq. 284 (2019) 639-646. https://doi.org/10.1016/j.molliq.2019.04.050.

[61] M. Fan, L. Ma, C. Zhang, Z. Wang, J. Ruan, M. Han, Y. Ren, C. Zhang, D. Yang, F. Zhou, W. Liu, Biobased green lubricants: physicochemical, tribological and toxicological properties of fatty acid ionic liquids, Trib. Trans. 61(2) (2017) 195-206. https://doi.org/10.1080/10402004.2017.1290856.

[62] P.K. Khatri, M.S. Aathira, G.D. Thakre, S.L. Jain, Synthesis and tribological behavior of fatty acid constituted tetramethylguanidinium (TMG) ionic liquids for a steel/steel contact, Mater. Sc. Eng. C 91 (2018) 208-217. https://doi.org/10.1016/j.msec.2018.05.038.

[63] C. Smith, The C=O bond, part VI: esters and the rule of three, Spectroscopy 33(7) (2018) 20-23.

[64] W.C. Barnhill, H. Luo, H.M. Meyer, C. Ma, M. Chi, B.L. Papke, J. Qu, Tertiary and quaternary ammonium-phosphate ionic liquids as lubricant additives, Trib. Lett. 63(22) (2016) 1-11. https://doi.org/10.1007/s11249-016-0707-6.

[65] D. Blanco, P. Oulego, D. Ramos, B. Fernández, J.M. Cuetos, Model-free kinetics applied to evaluate the long-term thermal stability of three [NTf2] anion-based ionic liquids, Thermoch. Acta 656 (2017) 70-84. https://doi.org/10.1016/j.tca.2017.08.002.

[66] F. Mangolini, A. Rossi, N.D. Spencer, Influence of metallic and oxidized iron/steel on the reactivity of triphenyl phosphorothionate in oil solution. Tribol. Int. 44 (2011) 670-683. https://doi.org/10.1016/j.triboint.2010.02.009.

[67] T. Mayer, Black spots on carbon steel after contact to lubricating oil with extreme pressure additives: an XPS study. Appl. Surf. Sci. 179 (2001) 257-262. https://doi.org/10.1016/S0169-4332(01)00292-6.

[68] Thermo Scientific, XPS Interpretation of oxygen. https://xpssimplified.com/elements/oxygen.php (accessed 3 August 2019). 